\title{
LYRIC DOUBLE TALK IN HORACE'S ROMAN ODES (ODES 3.1-6)
}

\author{
$S$ Thom (University of Stellenbosch)
}

Traditionally Horace's Roman Odes have been read as odes expressing what Santirocco has called a "major political statement". 'That this major political statement has not always sat easily on the lyric vehicle chosen to convey it has also been clear. ${ }^{2}$ Horace, more than most, probably realised that individual freedom and opportunities, to a large extent depend on a stable framework of government. ${ }^{3}$ After all, Horace's and Vergil's generation had reason to appreciate fully the benefits brought about by Augustan political change. ${ }^{4}$ At the same time Horace's Roman Odes cannot be taken at face value only. ${ }^{5}$ All the odes together including the Roman Odes, are an expression of a lyric poet's true genius. ${ }^{6}$ Even at his most solemn, as a supportive citizen of Rome and Augustus, Horace should be read with this larger perspective in mind.?

This article does not have in mind a new reading of Horace's Roman Odes. Instead it intends to comment on what has been labelled the dominant versus oppositional debate (Santirocco 1995:231) by packing out the area of debate in a slightly different manner. I shall concentrate on the means Horace used to achieve his

1 Syndikus (1973:11) points to a didactic purpose behind the political statements in the Roman Odes. According to Santirocco (1986:110) "The book [book 3] stands apart from the others...because of the special character of the Roman Odes as a major political statement." See also Lohmann 1991:72-73 for a further political perspective. Schenker (1993:148 esp. n.7) gives a list of useful articles, commentaries and general works on Horace's achievements "on national and epic themes."

2 Cf. for instance Highet 1957:131; Grimal 1975; Shackleton Bailey 1982:44-45; Mader 1987:11; Michel 1992.

3 See Williams 1994:399 for a careful summary of Horace's sensitivity to larger issues: "In praise of Augustus lay the greatest danger that Horace would be regarded as a mere party hack if he failed to handle such praise with utmost (sic) originality of poetic vision."

4 See Grimai 1975:139 who emphasizes the fact that the odes were composed over a period of time. Cf. also the discussion on Horace's position in Augustan society in the chapter on "Horace, Mercury, and Augustus" in Miller 1994:141-168.

5 Cf. Pöschl 1970:148 who points to the importance of Horace's use of terminology, “... [die Terminologie]...mit der er seine dichterische Sendung umschreibt, das Umstürzende seiner Botschaft andeutet und den Auftrag hoher Poesie in der augusteischen Welt kennzeichnet. Zugleich wird dadurch deutlich, welches $M a ß$ von Bereitschaft und geistiger und sittlicher Anstrengung von dem Horer einer solchen Botschaft gefordert wird."

6 Cf. the caution expressed by Miller (1994:4) on lyric expression in general: "lyric...is the representation mode of being a subject, in which the self exists not as part of a continuum with the community and its ideological commitments, but is folded back against itself, and only from this space of interiority does it relate to 'the world' at large."

7 It is important to realise just how individual Horace's contribution to Roman lyric poetry is. Cf. Von Albrecht 1995:290: "Sein Schaffen steht in seiner Art einsam da; es ist ausschießlich seine persönliche Leistung." 
end rather than on the end in itself, although the end will be present implicitly. ${ }^{8}$ In this paper I propose to read Horace's Roman Odes as lyric double talk in the sense that the views expressed in these odes, on the one hand, seem to support the new Augustan order but, on the other hand, they also seem to anticipate the criticism of somebody like Tacitus, in their staunch support of individual freedom, in their fervent expression of the personal rather than the group perspective and in their basic unease with a conformist or uncritical acceptance of the order of things.'

In short, in the Roman Odes as a whole, it seems as if Horace used language in general and double talk specifically, to suggest an implicit recusatio, reflecting a "poetic manifesto" (Fowler 1995:254) in which preference is clearly expressed (and argued) for the perspective embodied in a private or lyric world of personal awareness and responsibility as opposed to the perspective manifested in the public or political world of power and dominance. ${ }^{10}$ A recusatio relies on the fact that there are expectations embodied in a certain type of poem (or genre) to supply the basic material which can be reworked into a new reading of that poem (or genre). ${ }^{11}$ Just as deconstruction cannot take place in a vacuum, ${ }^{12}$ recusatio, to be effective, relies on a clear awareness and understanding of the expectations raised by a general reading of a specific type of poem but defeated in the particular language in which the recusatio is expressed. It is my contention that the poet of the Roman Odes, portrays this recusatio by using lyric double talk to say one thing ostensibly, but in reality to suggest something completely different at the same time. ${ }^{13}$

8 I accept without reservation Connor's statement (1981:1625) on Horace's political odes: "It is, in fact, his stability in, and his advocacy for the private sphere that gives him authority and confidence to tackle the problems of the public life."

9 Various critics have tried to come to terms with the ambivalence reflected in the Roman Odes. Some, like Nisbet and Hubbard, imply that Horace supported the Augustan regime, since he praised his benefactors (1970:xvii). Others point out that Horatian praise "consists more in warning than in laudation" (Johnson, 1982:138). Santirocco, who "emphasized the ideological aspect of Horace's Odes" (1995:231) takes a middle position by implying that Horace (in his high-minded Roman Odes, for instance) supported the regime and (in his light erotic verse) suggested a counterpart to such support.

10 Cf. Posschl (1970:149) who points out that the central idea in the first Roman Ode functions as "Aufruf zur Abkehr von der Macht- und Prunkgier". Schenker (1993:147 n.3) refers both to the immense bibliography on the two poetic spheres in Horace labled res publica and res privata and his own preference to discuss these spheres in terms of "poetic voice, or voices". In addition cf. Fowler 1995:264: "...the inheritance of Epicurean and Stoic moral philosphy on which Horace draws throughout his work, particularly when conjoined with Callimachean poetics to produce a Callimachean ethics, makes it impossible to produce successful panegyric." See also Grimal (1975:141) who points out that "les forces qui troublent l'âme humaine sont bien celles que dénonce la doctrine d'Epicure."

11 Cf. Davis 1991:11-39, esp. 28-39 for a thorough discussion of Horatian use of recusatio.

12 Cf. Dunn (1995:169) who defines deconstruction as "'new New Criticism' [which] recovers a play of rhetorical ploys and strategies only in the texture of poetic language itself...a rhetoric in which I and You are the text speaking to itself."

13 Cf. Schenker 1993:147: "he [Horace] not infrequently seems to embrace, simultaneously, two or more mutually exclusive positions." 
An obvious question comes to mind, however. Why would anybody go to the trouble of disguising poetry reflecting a legitimate individual perspective on life, as poetry ostensibly making a political statement or even supporting a specific political point of view? One could rephrase the question as follows: why would anybodythen or now-want to or need to coach their thoughts in terms of a specific political ideology? ${ }^{14}$ Or even, why does political change require an appropriate literary response? The obvious answer would be that such expression (literary or otherwise) must somehow be a response to pressure of some sort be it public opinion, peer pressure, personal awareness-the same types of pressure which create a climate for expressing "politically correct" sentiments in the modern world. Since "literature was important and writers important people" (Quinn 1981:79) in Horace's world, it follows that it obviously helped if writers toed the official line. ${ }^{15}$

Lyric double talk, since it represents the means to an end for Horace's recusatio in the Roman Odes functions by creating an expectation which is deflated or questioned by the very nature of the lyric vehicle used to create the expectation in the first place. This paper aims to trace Horace's defeat of expectations (his recusatio) in the sense that where the audience is led to "expect" a political statement coached in the appropriate language, in the Roman Odes this expectation is turned on its head and a personal perspective is suggested in its stead. A political statement might be reflected in each individual ode, but not necessarily the statement expressing an expected political point of view. Even more to the point, the statement might not necessarily be construed as political support in the first place. In short, according to a double talk reading the Roman Odes could be described not as a series of political poems concerned with traditional political themes, but instead as a series of lyric poems dealing with timeless ethical questions. Horace makes the political statement more or less expected of a supporter of the Augustan regime, but at the same time shows up this statement for what it is. In fact he sidesteps the issue of support for certain political perspectives by giving a lyric reevaluation of the very perspectives he supposedly supports. ${ }^{16}$

This article accepts that there is a general consensus why the Roman Odes were called Roman or a "major political statement" in the first place. I shall therefore

14 Cf. the chapter on "Requests and Pressure" in White 1993 and Santirocco 1995:225-243.

15 See again Quinn 1981:79: “...clearly Maecenas went out of his way to cultivate those from whom a poem about the achievements of the Emperor might be expected. Plainly the poem expected wasn't just one that flattered Augustus' vanity; what was wanted was a poem that would have a predetermined impact upon an audience large enough to make that audience a significant political factor." On the other hand, Martindale and Hopkins (1993:21) seem to suggest that Horace advocates rather "the politics of privacy". They (with Zanker 1988) point to a private sphere (of luxury and aesthetic pleasures) where an enfeebled aristocracy could ignore (and by implication accept) the transition to one-man-rule. Cf. also Miller 1994:2-4 on lyric genre in general as "a projection of a peculiarly interiorized and articulated consciousness".

16 This can no longer be construed as "support". On the contrary, when the poet reevaluates the going political perspectives in lyric terms, he implies criticism of those political values. See Michel 1992:133 who points out: “...plus largement et plus exactement que la sagesse d'un poète ne peu être que poétique." 
not first trace the expectations raised in individual odes before debunking them. The focus will be on a sub-text, suggested by a specific proposed perspective in the Roman Odes, which Horace is at great pains to point out at the very beginning of the cycle.

Odes 3.1. In the first stanza of the first ode of Book 3, the poet explains his own rôle in this book, indicating the character of his work and giving precise instructions to his audience. ${ }^{17}$ The point of view will be personal: the cycle starts with an emphasis on the ' $\mathrm{I}$ ' in odi (v.1). ${ }^{18}$ The poet specifies that he is a musarum sacerdos (v.3), a priest of the Muses serving their interests, interpreting their views, benefitting from their inspiration, and, by implication, making it clear that he is, in the first place, not a priest of the Roman state, ${ }^{19}$ even though he might be using vocabulary associated with such a position. His activity is lyric poetry, epitomised in canto (v.4). ${ }^{20}$ Lyric double talk would suggest that the audience is expected to pick up and focus on this difference from the beginning of the cycle. The poet's work is his carmina (v.2) understood only in silent individual concentration (as a reference to favete linguis [v.2] would imply), understood not by the unhearing, uncritical masses (the profanum vulgus, v.1), but by people who will come to these carmina with an open mind, a fresh appreciation of what the poet has to say, as indeed the poet could expect from virginibus puerisque (v.4).

With this proviso concerning the poet, the poems and the audience in mind the reader can now turn his attention to the rest of the first poem and to the following Roman Odes as well. After the extremely simple language of the first stanza of Odes 3.1 , the structure of the second stanza is complex, making maximum use of the possibilites of an inflected language. The battle between the giants and the Olympians may be an epic favourite celebrating one of the great triumphs in mythology, but the lyric perspective cuts the whole down to size. Authority is never absolute: imperium (v.6) only has power in proprios greges (v.5). In other words, right at the beginning of this first Roman Ode, where authority is ostensibly established, Horace undermines the concept of absolute authority and points out that, irrespective of one's position, all authority is subservient to a higher power. All creatures stand under a higher law, the

17 Cf. Pöschl 1970:148-9.

18 Cf. Fraenkel 1957:264: “....we expect that the emphasizing of the ' $\mathrm{I}$ ', of the individuality of the poet, will be of great importance to the message of the carmina non prius audita"; and Davis 1991:121: "The proem to the so-called Roman Odes brandishes the word odi as a way of excluding, at the outset, an unsophisticated audience (profanum vulgus) before announcing an innovative poetic program (C. 3.1.1-4)."

19 Cf. Silk 1973 who points out that the carmina non prius audita (3.1.2-3) should rather refer to poetry not previously understood, rather than not previously heard. Further, cf. Schenker 1993:150 who states: "Thus, our initial first-person encounter with the poet reveals him as removed and authoritative, elevated above the many types of people he then presents as both positive and negative exempla."

20 The audience knows from an earlier ode (Odes 1.6) that scribo refers to writing epic verse and canto to composing lyric poetry and that these two activities represent a very different perspective on life. 
completely impartial law of Necessity (aequa lege Necessitas sortitur insignes et imos, vv.14-15). ${ }^{21}$

This second stanza of the first Roman Ode is a persuasive example of lyric double talk. Ostensibly the stanza celebrates authority. Imperium, after all, is the achievement celebrated by a triumph of which Augustus had celebrated a number at this stage of his career. ${ }^{22}$ But lyric language specifies that this imperium is only over an own flock (in proprios greges, v.5), slyly cutting the imperium as well as the imperator down to the level of the common herd. Lyric double talk seems to suggest that whether one is an ordinary sheep or the leader of the flock, the reality to remember is that one is still only a sheep. ${ }^{23}$ The lyric perspective then seems to suggest that depending on one's position, one's experience of and perspective on reality might change. Ironically the lyric perspective seems to go even further by suggesting that the more ordinary the life one leads, the easier it probably is to keep this relativity in mind. ${ }^{24}$

In this first poem of the cycle Horace firmly establishes the basis on which his Roman Odes should be judged. The ode begins and ends with a celebration of the poet's personal perspective on the situation: odi (v.1) and canto (v.4) in the first stanza and moliar (v.46) and permutem (v.47) in the last stanza. This personal perspective functions in terms of the poet's understanding of essentials and operates as an individual corrective of general assumptions, both reflected in the central tenet of the poem: desiderantem quod satis est (v.25). This personal perspective gives a realistic assessment of the true burden of riches or influence or even, to return to the beginning of the poem, the burden of power, namely that the benefits of all these are relative. In this first poem the contrast between the public image of a man (whether he is rich, influential or powerful) and the private experience of his life (whether he actually can sleep at night) is worked out in great detail. The poet wants his audience to be very clear about one basic assumption: assessment of a life depends on one's point of view. At the same time success in the political arena does not automatically translate into success as a human being. In Odes 3.1, for instance, none of the vagaries of fortune will overwhelm him who desires only what he needs desiderantem quod satis est (v.25). It is when what the farm (v.30) promises is confused with what the farm delivers, when expectations become unrealistic, that the farm becomes a disappointment and becomes a fundus mendax (v.30). ${ }^{25}$ According to the criticism

21 Cf. Silk 1973:144 who argues that Necessity "does not have anything to do with death but with life", and further that "there is no escape" even in this life, from the law of Necessity.

22 Cf. Res Gestae 4.1, 4.4. Although the date of Augustus' Res Gestae is usually taken as $\mathrm{AD} 13$ much of its content would have been drafted long before then. And even if the content of the work were not generally known, Augustus' career was one long fight to establish his own imperium.

23 Cf. Syndikus 1973:16.

24 Syndikus 1973:19: "Aber nun erfahren wir, daß für den Menschen im scheinbar Alltăglichsten und ohne Muhe Erreichbaren das Glück und das Heil liegen kann."

25 Another striking use of mendax occurs in Odes 3.11.35 where Hypermestra does not deliver what was promised either. The fact that "what was promised" was the murder of her newly wedded husband puts a completely different perspective on mendax in this ode. 
implied by the lyric point of view, it is a confused personal perspective that could turn a valle...Sabina (v.47) into this fundus mendax (v.30).

In the last stanza of the poem Horace does not only express his personal preferences, he indicates the basic, but at the same time very simple, motivation for the recusatio worked out in all six Roman Odes. The divitias operosiores (v.48) of panegyric do not tempt him, because on the most basic level what needs to be praised does not convince him. The lyric poet, Horace, does not come out with a major political statement, because he is not a political creature. ${ }^{26}$ Instead he comes out with a statement that sounds political or rather sounds politically correct, but which on closer scrutiny undercuts the very basis of politics, namely that basic quest for power. After all, a lyric poet by virtue of the distinct quality of his voice, cannot produce the right tone for panegyric. Lyric double talk subtly suggests that power and politics are fine, but, at the same time, rather limited if measured by a different yardstick, the lyric perspective. So we end up with a basic contradictio, namely that imperium is, after all, limited.

Odes 3.2. In the following poems lyric double talk will play repeatedly on incongruities of tone or perspective to influence understanding of a specific poem. If Odes 3.1 underlined the personal perspective as a type of pointer, it appears as if the following ode (3.2) could be a prime example of praise for sweeping political achievement in a patriotic Roman Ode, since it seems to extol those very qualities which made Rome great in the first place. ${ }^{27}$

The first three stanzas focus on the Roman soldier whose endurance and courage in the field transformed a small settlement into an empire. The fourth stanza contains the famous exhortation to glory: dulce et decorum est pro patria mori (v.13); while the fifth and sixth stanzas seem to extol principle of character and its rewards. The alert reader, however, will take note of Odes 3.2's own warning signals against "expectations". The second half of the ode and the last two stanzas in particular pose a problem to a generally politically supportive interpretation of the ode, since here something as passive as silence, too, can claim, not only a reward, but a sure one (tuta merces, vv.25-26). Odes 3.1 has warned the reader of possible discrepancies arising from different perspectives, discrepancies between appearances and reality: not the farm but the owner's expectations of the farm are false; not power necessarily but limitless expectations of power can turn out to be deceptive.

However, it is more to the point to note that this second Roman Ode only superficially extols the rewards of the soldier's courage. ${ }^{28}$ It is quite clear in his description of the soldier that Horace wants his readers to be aware of the possibilites of different perspectives on this soldier. From a Roman point of view this young

26 Contra Schenker 1993:150 who argues that "when the poet returns to the first person at the end of the ode, he has altered his identity".

27 Cf. Lohmann 1991:62-75. For references to further interpretation problems of this ode see Schenker 1993:159 n.47.

28 Contra Syndikus 1973:27: "Er [Horaz] hat einige römische Grundpositionen so unreflektiert als fraglos richtig abernommen, daß er sich des Widerspruchs zu seiner sonst eingenommenen philosophischen und menschlichen Haltung nicht einmal bewußt wurde." 
soldier may be considered well-trained and well-disciplined (robustus acri militia puer, v.2), but from the enemy's point of view the same soldier is a savage beast propelled by a bloody rage. Dulce et decorum est pro patria mori (v.13) is therefore an extremely cynical maxim, following, as it does, immediately upon a description of the soldier's activities likened to those of a beast of prey, wild for blood. One is further tempted to ask for whom is it dulce et decorum that the soldier dies-presumably only for the memory of the dead soldier by people who have turned carnage, after the fact, into something heroic. The individual perspective sees the act for what it is, the collective perspective concentrates on the gains achieved as a consequence of the act. ${ }^{29}$ If the reader had missed the significance of the juxtaposition between the bloody bestial rage at the end of stanza three and the sweetness and glory of the memory of that same act at the beginning of stanza four, the rest of stanza four should suffice to make him pay careful attention: death overtakes all--the hero as well as the coward. From the perspective of extending the empire and establishing Roman imperium, individual death is suffered and individual duty maintained for the greater good of society, therefore the politically correct perspective supports the idea expressed in i.a. dulce et decorum est pro patria mori (v.13). At first glance, lyric double talk seems to support this point of view, but at the same time, because of the placing of this phrase, it forces the reader to scrutinise the meaning of the words in a larger context. In the final analysis the phrase queries the maxim rather than supports it. The lyric perspective questions this pat reward for individual death or duty since death eventually spares no-one, neither hero, nor coward. In general the civilian's duty or courage in the private sphere may not be seen to match the soldier's courage in military matters. As Horace's lyric double talk has just pointed out, however, more than one perspective on both types of courage is possible. It seems then that $s u b$ specie aeternitatis and from the lyric perspective, the soldier's courage does not surpass the civilian's duty in value.

In the first four stanzas of the poem, personal reward in terms of the greater good of society is extolled as incentive for one of the great political virtues: the courage to lay down one's life for an idea. Personal reward in terms of the good for the individual comes to the fore in the last four stanzas of the poem. They reflect the personal perspective on virtue not in terms of dying for the greater good of society, but in terms of the opening of heaven to the living by means of personal understanding. Lyric double talk seems to be suggesting that pro patria mori (v.13) may be the politically correct thing to do for those who want renown on earth, but that true lyric insight or virtus would argue for the opposite course of action: opening up heaven for those who do not deserve to die (recludens immeritis mori caelum, vv.21-22) - those who do not deserve to die because they have deeper understanding of what it means to live.

According to the political definition of the characteristic, virtue requires courage up to the point of sacrificing life. Virtue, according to the lyric perspective,

29 Witke (1983:70) points to the "tension between the two worlds of peace and war, personal pursuits and collectivized action...". Cf.also Schenker (1993:147) who states that "antithesis has long been recognized as one of the hallmarks of Horatian poetry." Cf. also Connor 1972:245-48. 
however, requires the same effort, but with the opposite result as is clear in immeritis mori (v.21). Lyric virtue does not manifest itself in group action, but rather in individual reflection. Silence (fideli...silentio, v.25) implies contemplation and a quest for understanding fully, just as favete linguis in Odes 3.1.2 was a prerequisite for concentration with a view to achieving understanding. Silence at the end of this poem is put on a par with courage in military matters and self-sacrifice. The world of military and political power needs the death of the individual to establish its imperium. The lyric world concentrates on the triumphant survival of the individual through greater understanding: recludens immeritis mori caelum (vv.21-22). Since the poem ends with an endorsement of silence and the understanding it represents, it would seem that lyric double talk in this poem supports the individual perspective, and by implication rejecting the point of view reflected in dulce et decorum est pro patria mori.

Odes 3.3. In Odes 3.3 the lyric and political perspectives on life are not only contrasted but also integrated. The body of the poem reflects political themes and concerns from the earliest times up to Augustus' present reign. Augustus' eventual political success is symbolised by his drinking nectar with the other immortals: Pollux et...Hercules, quos inter Augustus recumbens...bibet...nectar, vv.10-12). But Augustus' success, as the success of the epic heroes mentioned here, depends not on his political achievements or his military triumphs, but in the first place on his individual worth, on being just and principled (iustum et tenacem propositi, v.1), on maintaining the individual perspective, on not bowing to pressure from the masses (civium ardor, v.2). In short, lyric double talk slyly celebrates the ideal epic or political hero, and this hero's success, but in terms of the values normally regarded as important in the lyric world.

Not only the language, but the structure of Odes 3.3 too reflects political achievement in terms of lyric values..$^{30}$ The introductory stanzas (one and two) dwell on individual worth even in the face of cataclysmic disaster, and the final stanza turns its back firmly on epic-political subject matter to celebrate instead poetry with a lighter touch (iocosae...lyrae, v.69). Thus lofty epic themes are encircled by, and in the final analysis subjected to, individual perspective.

It is clear that even in this ode where Augustus is portrayed as achieving the highest honours known to the poet when praising political achievement (arces attigit igneas, v.10), the lyric poet suspends judgement. Political success is not necessarily suited to lyric praise. Juno may announce the cessation of her epic wrath against Rome, but the lyric poet reaffirms that it is not the sermones deorum (v.71) that is his true concern but rather the more modest endeavours of the individual.

Even in this poem, where the reader has been led to expect an appreciation and endorsement of political achievement, this expectation is defeated in the last stanza. One of the functions of a recusatio is to prove ability at the same time as

30 Fraenkel (1957:267) points out the connection between the structure of Odes 3.3 and Odes 3.5, both odes being dominated by speeches. Odes 3.3 contains the Juno speech and Odes 3.5 the long Regulus speech. 
denying it. ${ }^{31}$ Lyric double talk has seemingly been kept at bay, only to come into its own at the end of the poem. The fact that Horace ostensibly has to call his own Muse to book for creating these false expectations of praise for political achievement, illustrates just how pervasive expectations can be. Horace's audience can hardly be blamed if they followed where his Muse led so persuasively. It is as if Horace wants to lay the blame for the false expectations created by his epic-like poem at the door of his Muse (quo, Musa, tendis? v.70). His final comment that his poem detracts (tenuare, v.72) from the value of the political achievement described, is a clear indication of lyric double talk, of his iocosae ...lyrae (v.69) in action. His poem, after all, started with a description of a virum...iustum et tenacem propositi (v.1) unaffected by the ruin of the world, untouched by just such actions of gods and men as were described in this poem.

Odes 3.4. If Odes 3.3 evaluates political themes in terms of the lyric perspective, Odes 3.4 motivates the lyric experience in terms of a political perspective. The lyric poet's quest for immortality is compared to the epic hero's quest for the same thing. The means of achieving this aim may differ, but the quest requires the same singleminded dedication.

Odes 3.4 is dedicated to Calliope. This invocation of the Muse in the first two stanzas of the poem indicates the seriousness of the poem which follows. ${ }^{32}$ But at the same time the lyric point of view is emphasized since the poem is the result of inspiration in the tradition of great Greek lyric poets like Pindar, Sappho and Alcaeus. $^{33}$

In the following seven stanzas (vv.9-36) the poem gives a summary of the poet's experience from childhood where he is described as non sine dis animosus infans (v.20) until, as Musarum sacerdos, he can visit the farthest and most dangerous limits of the Roman empire unscathed (inviolatus, v.36). Under the auspices of the Muses he is a navita libens (vv.20-30) exploring the limits of reality in his quest for new horizons of understanding to incorporate in his poetry. ${ }^{34}$ In spite of the very real dangers of this quest (war or dangers on land and sea are mentioned here [vv.26-28]) the poet remains inviolatus (v.36) because the Muses are with him (mecum vos eritis, v.29).

Surprisingly enough with their gentle counsel (lene consilium, v.41) the Muses can also support Augustus as Caesarem altum (v.37) in his political

31 Or as Schenker (1993:153) puts it: "In the very act of professing his limitations as a lyric poet, or his inability to treat grand, important, or political themes, Horace gives himself license to treat those themes."

32 For an exposition of the basic three-part structure of the poem, see Schenker 1993:156.

33 Horace indeed refers to the flute representing choral lyric and the lyre representing monody or odes like Horace's own. Fraenkel (1957:276-281) discusses the connection between Pindar's first Pythian ode and Horace Odes 3.4 in detail.

34 Cf. Odes 1.3. Cf. also Davis (1991:98-107) who characterizes the "entire first half of the poem as prooemial" and goes on to state that "only a magnificent subject would necessitate so qualified a bard and so prolonged an overture" (106). 
endeavours. ${ }^{35}$ Even though Augustus' quest takes place in a different world, the world of strife epitomized by the clashes between Gods and giants in their striving for supremacy, or the political world where imperium has to be established and expanded, he will benefit from the support of the Muses-not from their inspiration, as does the lyric poet, but from their gentle counsel for leniency. Ironically the counsel of the Muses is to limit the very power that is normally the aim of the epic hero's quest and certainly the aim of any political power seeker. ${ }^{36}$

Again the original expectation created by the poem has subtly been defeated. The hero's quest for power seems to parallel the poet's quest for true understanding. Both can benefit from an association with the Muses. The lyric poet, however, is fully supported and protected by the Muses in his quest while the political hero receives no support, only advice to limit the very aim of his quest. In this poem lyric double talk seems to be used to embody a warning to Augustus: power without counsel falls by its own weight; the gods make tempered power even greater (vis consilii expers mole ruit sua: vim temperatam di quoque provehunt in maius, vv.65-66).

The poem ends with a veiled threat: a telling description of two mythological characters whose own passions of epic proportions are now forcibly curtailed by external factors: Tityos (a giant) with the seat of his emotions, his liver, repeatedly eaten out by a vulture and the Lapith Pirithoous bound by three hundred chains and forced into inactivity. This final stanza seems to suggest not only a preference for the lyric poet's quest, but serious reservations about the political hero's often arrogant aims. Accepting a limitation to the aim of his quest however, undermines the very basis of the political hero's way of life.

Odes 3.5. Horace's basic unease with the limited mind-set of power politics is exposed even further in the next ode. The first stanza of Odes 3.5 gives examples of positions of power both in heaven and on earth. Both seem to depend on perception more than reality: we believe that Juppiter reigns in heaven, because we hear him there; that Augustus will be considered a god once the military aim of conquering the Britons and the Parthians have been attained. Both beliefs are a matter of opinion, not fact. It seems then as if the poet is again questioning the political aim for domination and power as he did in the previous poem.

In the second and third stanzas the poet points out one of the ironies caused by political ambition based on the achievements of military conquests. The soldier whose efforts made a greater Rome possible, grows old in ties created because of these war efforts (miles...coniuge barbara turpis maritus vixit, vv.5-6) and forgets the real Roman symbols and values such as the Roman name and toga and the eternal flame of Vesta for which he originally fought. Is this then the basis of real power?

The lyric poet answers this question very carefully in the rest of the poem. He is not stirring up political fervour to revenge military battle losses as might be

35 On the shift from Horace to Augustus as recipient of the support of the Muses, see Wilkinson 1945:70.

36 Apollo embodies the link between military (v.60) and poetic activity (vv.61-64). By implication Horace is pointing out that help even in military matters (which Jupiter, too, had to use) comes via the Muses and poetry. 
expected in terms of the basic political aim for domination and power. He instead gives a description of the choices faced and made by a single specific historic individual, Regulus, indicating clearly that real power depends on individaul understanding and responsibility. Political hunger for power has as a consequence the unspecified miles who forgets the very symbols of the Rome for which originally he was prepared to sacrifice his life. The lyric quest for understanding is symbolised by Regulus, an epic hero who transcends the political norm, who grasps that actions have consequences (perniciem veniens in aevum, v.16). Regulus' own words are quoted (vv.18-40) making a direct appeal to the reader to judge the reality for himself. It further functions as a sharp contrast to the vague perceptions held about power described in the first three stanzas of the poem.

Regulus' speech is a masterpiece of persuasive political rhetoric. I mention only a few aspects. He speaks as eye-witness reporter of Rome's shame (cf. the repetition of vidi, vidi, v.21). Each point he makes is not only well-motivated by preceding argument, it is also expressed in a simple memorable phrase for instance "to shame you are only adding loss" (flagitio additis damnum, wv.26-27) or "such a man confuses peace with war" (hic...pacem duello miscuit, v.38), or finally, "O mighty Carthage, built higher on the downfall of Italy" (o magna Carthago probrosis altior Italiae ruinae, vv.39-40). The world of war and politics and its ideals have a proud spokesman indeed in Regulus. It seems then as if the poet is contrasting two types of characters which emerge as a consequence of a political reality: the unknown miles who represents the negative aspect and Regulus who represents the ideal. And if the poet were writing political panegyric no doubt the poem has proved its point. But the lyric poet is interested in a slightly different point of view which is brought into play in the last four stanzas.

This section of the poem illustrates the close connection as well as the real clash between the lyric point of view and that of power politics. The setting aside of Regulus' family ties are described in terms of the loss of his civil liberties (ut capitis minor, v.42) underlining how intimately the life of the individual is connected to his standing in society. Verses 41 and 42 , however, do not contain the first description of family ties in this poem. Right at the beginning of the poem the life of the soldier forgotten by the state is depicted. Not only Regulus' honourable Roman wife and offspring (pudicae coniugis parvosque natos, vv.41-42) are contrasted to the alien wife (coniuge barbara, v.5) whose very existence shamed her husband (turpis maritus, v.6). The two husbands are also in striking opposition to each other. The unspecified miles grew old under Roman shame (vixit et...consenuit, vv.6 and 8) finally forgetting the very essence of Rome (anciliorum et nominis et togae oblitus aeternaeque vestae, vv.9-10). Regulus forces the Senate to remember their shame and to face the consequences. Ironically it is the single outstandingly honourable individual who leaves the group as exile (egregius...exsul, v.48), whose action comments implicitly on that of the group as a whole.

The last two stanzas portray the true lyric hero. His individual standard of conduct is unaffected by collective inadequacies or pressure. He is not daunted by foes nor swayed by friends. He makes a very realistic assessment of the consequences 
of his choices (atqui sciebat quae sibi barbarus tortor pararet, vv.49-50). Regulus' action might be termed heroic but his frame of mind reflects the lyric ideal: a man who has attained that peace of mind normally associated with one who knows his own mind, whether it is to stick to his principles (tenacem propositi, as advocated by Odes 3.3.1) or whether it is to keep things in perspective even when the world about him collapses (impavidum ferient ruinae, Odes 3.3.8). ${ }^{37}$

Once again the expectations evoked by the poem seem to have been defeated. Odes 3.5 is not intended as a call to arms to avenge shame and conquer the present enemies of Rome, as the first great enemy of Rome, Carthage, was defeated. It is not even a comparison between the political ideal embodied in Regulus' action and the lyric ideal reflected in Regulus' understanding of the need for and consequences of his action. In the final analysis the poem is the lyric celebration of one individual's personal choice. That this man happened to be a soldier, happened to embody the political ideal, that his choice happened to be made in terms of political realities, should, however, not lead the reader to expect to judge the poem only in terms of political criteria. That would be missing the point, that would implicitly be calling the bluff of the poet's lyric double talk.

Odes 3.6. The last of the Roman Odes, Odes 3.6, shocks the reader by its unexpected opening phrase delicta maiorum (v.1) instead of the standard reference to mos or mores maiorum. It is clear that the poet, at the end of this poetic cycle, wants to reconsider some of the issues reflected in the previous Roman Odes. ${ }^{38}$

Odes 3.6 is simply structured. In the first six verses the need for understanding the principle which governs the life of mortals is established. This same principle is exemplified by the thoughtful individual perspective extolled in desiring quod satis est in Odes 3.1 or embodied by Regulus's choice in Odes 3.5. If this principle is ignored, if false expectations (of gain, or glory or power, for instance) obscure individual understanding, the comprehensive woes described in the main section of Odes 3.6 soon follow: military disaster abroad and at home (vv.7-16) and the disintegration of civil society (vv.17-32). The last section of the ode (vv.33-44) gives a description of the simple, even limited way of life which would never turn a valle...Sabina (Odes 3.1.47-48) into a fundus mendax (3.1.30).

The last stanza of this ode brings the whole cycle to a close. It incorporates a dire warning about the epic consequences of ignoring the lyric perspective. The ode shocked the reader by its opening reference to the delicta maiorum (v.1) in the past. It closes with the equally shocking prophesy of a progeniem vitiosiorem (v.48) in future. Even though the references are to the ancestors or to future generations, the individual Roman of the present is addressed in Odes 3.6. The individual perspective as embedded in the lyric poet's defeat of expectations forms the basis for the thoughtful understanding needed to combat the ills in any situation, be they collective or personal.

37 Contra Schenker 1993:153 who describes the theme in Odes 3.5 as "the integrity of the state" taking "precedence over the well-being of the individual" and that "Regulus himself exemplifies that priority by turning his back on family and friends $(41-48)$ in service to the state".

See Schenker 1993:163 nn. 61, 62 \& 63 for a list of negative criticism on this specific ode. 
Since expectation must logically reside with the reader of the poem, the "false" expectations created and defeated, as pointed out by this paper, must be ascribed to the reader. If Augustas or Maecenas expected some poetic support from Horace as an amicus he has at least shown himself more than worthy of their support of him as a poeta even if he did not produce exactly what they might have expected as far as subject matter was concerned. ${ }^{39}$

Odes 3.7-12. The reader is not, however, expected to gain these insights only by his own efforts. The poet of the Roman Odes gave careful indications of alternative readings not only in the individual poems but also in placing the Roman Odes in a specific larger context. If the poet hinted by the use of lyric double talk and other means more or less directly at a different perspective on some of the issues discussed in the six Roman Odes, this alternative (individual) perspective is celebrated openly and triumphantly in the next six Odes (3.7-12). If Horace concentrated on the lyric perspective in the Roman Odes as an alternative to the political or military view of a situation, the poet seems to take great joy in the next six odes in using the same strategy of playing with different perspectives on the same situation, to exhibit the skill of his iocosa lyra (3.3.69) when the subject matter is more suited to his Muse.

In short, Horace returns to the lyric mode and lyric subject matter with a vengeance in Odes 3.7 and following. No fewer than four individual perspectives on the same situation are indicated in Odes 3.7: Asterie worrying about the possible faithlessness of her lover stranded in the East; the faithful lover, Gyges, missing his beloved; his hostess, Chloe, who (ironically) calls on examples from the epic tradition to try and tempt her uninterested guest; and back home again, Asterie who might also, because of the absence of her lover, become interested in her neighbour Enipeus. The same sure touch of the poet of the Roman Odes prevails here too, however. The poet of the first Roman Ode had the sense to prefer his Sabine valley to troublesome riches. It seems as if something as simple as a different perspective can, also in Odes 3.7 , solve Asterie's problem or at least dry her tears; when the focus changes from the absent lover's temptation to the girl's own very real temptation right next-door.

Odes 3.8 parades the lyric advantage in a different way. What does it matter to the lyric poet if the 1 st of March is the festival of the Matronalia and not to be celebrated by a bachelor? From a personal perspective he has something to celebrate. In the same way Maecenas, in spite of his immense civic responsibilities which, by the way, are rather slyly described in somewhat grandiose epic terms, can join his friend's festivities as a privatus (3.8.26) for a few hours. Did not Odes 3.2 make it quite clear that irrespective of individual merit, death overcame all?

That most charming of poems Donec gratus eram tibi (Odes 3.9) depends on shifts in personal perspective for much of its effectiveness. At the same time it very neatly puts the individual cases for both sexes in a personal relationship. Odes 3.10 places the exclusus amator in an epic environment to underline the lover's present non-conventional and personal perspective on the disdainful Lyce. In Odes 3.11 Hypermestra is not only described as splendide mendax (3.11.35), but the epic 
example of her softheartedness is surely meant to be a pointer to the skittish Lyde. And if Odes 3.10 and 3.11 concentrated on the male experience of a troublesome relationship Odes 3.12 reflects an unexpectedly realistic female perspective.

The final comment on both the lyric perspective reflected especially in the use of lyric double talk in the six Roman Odes as well as the lyric world portrayed in the next six odes, is summarized in the fons Bandusiae ode, Odes 3.13. It is the sparkling life-giving water of the spring which makes the scorching reality of summer bearable for the herd. It is the lyric poet's creative perspective on life which leads his audience to a new and revitalized view of the world-the political world of power and dominance just as much as the lyric world of personal relationships.

\section{BIBLIOGRAPHY}

Connor, P J 1972. The balance sheet: Considerations of the second Roman Ode. Hermes 100:245-48.

Connor, P J 1981. The actual quality of experience: An appraisal of the nature of Horace's odes. ANRW 2.31.3:1625-1639.

Davis, G 1991. Polyhymnia: The rhetoric of Horatian lyric discourse. Berkeley: University of California Press.

Dunn, F M 1995. Rhetorical Approaches to Horace's Odes. Arethusa Horace: 2000 Years 28.2-3:165-176.

Du Quesnay, I M Le M 1995. Horace, Odes 4.5: Pro reditu imperatoris Caesaris divi filii Augusti. In Harrison, S J (ed), Homage to Horace: A bimillenary celebration, 128-187. Oxford: Clarendon Press.

Fowler, D P 1995. Horace and the aesthetics of politics. In Harrison, S J (ed), Homage to Horace: A bimillenary celebration, 248-266. Oxford: Clarendon Press.

Fraenkel, E 1957. Horace. Oxford: Clarendon Press.

Grimal, P 1975. Les 'Odes romaines' d'Horace. REL 53:135-156.

Highet, G 1957. Poets in a landscape. New York: Knopf.

Johnson, R W 1982. The idea of lyric: Lyric modes in ancient and modern poetry. Berkeley: University of California Press.

Lohmann, D 1991. Horaz carmen III 2 und der Zyklus der 'Römer-Oden'. $A U$ 34:6275.

Mader, G J 1987. Poetry and politics in Horace's first Roman Ode: A reconsideration. AClass 30:11-30.

Martindale, C and Hopkins, D 1993. Horace made new. Cambridge: Cambridge University Press.

Michel, A 1992. Poétique et sagesse dans les Odes d'Horace. REL 70:126-137.

Miller, P A 1994. Lyric texts and lyric consciousness. London: Routledge.

Nisbet, R G M and Hubbard, M 1970. A commentary on Horace: Odes: Book I. Oxford: Clarendon Press. 
Pöschl, V 1970. Horazische Lyrik: Interpretationen. Heidelberg: Carl Winter Universitätsverlag.

Quinn, K 1981. Poet and audience in the Augustan Age. ANRW 2.30.1:75-180.

Santirocco, M S 1986. Unity and design in Horace's odes. Chapel Hill: University of North Carolina Press.

Santirocco, M S 1995. Horace and Augustan ideology. Arethusa 28.2-3:225-243.

Schenker, D J 1993. Poetic voices in the Roman Odes. CJ 88.2:147-166.

Shackleton Bailey, D R 1982. Profile of Horace. Cambridge: Harvard University Press.

Silk, E T 1973. Towards a fresh interpretation of Horace Carm. III.1. YCS 23:131145.

Syndikus, H P 1973. Die Lyrik des Horaz. Darmstadt: Wissenschaftliche Buchgesellschaft.

Von Albrecht, M 1995. Horaz und die europäische Literatur. Gymnasium 102.4:289304.

White, P 1993. Promised verse: Poets in the society of Augustan Rome. Cambridge: Harvard University Press.

Wilkinson, L P 1945. Horace and his lyric poetry. Cambridge: Cambridge University Press.

Williams, G 1994. Public policies, private affairs and strategies of address in the poetry of Horace. $C W$ 87.5:395-408.

Witke, C 1983. Horace's Roman Odes: A critical examination. Leiden: Brill.

Zanker, P 1988. The power of images in the age of Augustus. Ann Arbor: University of Michigan Press. 